\title{
Roles of Organizational Support as a Moderator Relationship between Personality and Employers' Performance: A Case of Customer Service in Banking Industry of Kupang City- Indonesia
}

\author{
Roberth M. Noach, Pieter D. Samadara, Stela Sahetapy \\ \{robert.niach95@gmail.com, pietersamadara.adbis@gmail.com, \\ stellasahetapy3@gmail.com \\ Administration and Business Department, State of Polytehnic Kupang
}

\begin{abstract}
This study is aimed at analyzing the influence of personality towards performance, organizational support towards performance, as well as organizational support as a moderator of the relationship between personality and employers' performance in the banking industry in Kupang City, East Nusa Tenggara Province, Indonesia. The research sample was 92 respondents from a total of 124 customer service (CS). The analysis was conducted using moderation regression (MRA) with SPSS Version 20. The results showed that (1) personality has got a significant effect on performance, (2) organizational support has got a positive and significant effect on performance, and (3) organizational support has got a significant positive effect in moderating the relationship between personality and employers performance
\end{abstract}

Keywords: Personality, Organization Support, Employers Performance, Customer, Service, Bank.

\section{Introduction}

\section{Background}

Many factors have influenced individual performance and organizational performance. These factors come from the availability of resources in an organization. The availability of Human Resource (HR) and the behaviours exhibited by each individual or group in the organization, theoretically, impact the performance. Personality factor is also one of the factors that influences employers' performance. [1] states that a person's personality can be seen from how he reacts with people. Personality itself is formed from heredity, environment and the situation in which he is located. In the other side, McCrae, et al. [2] state that personality is influenced by biological factors.

[3], [4], [5], and [6] have conducted researches and concluded that personality influences performance. In contrast, [7], [8], [9], and [10] have shown the different results, and thus, presented different statement.

Referring to the inconsistency of the results of the previous study, the improvement in employers' performance needs to be further considered. Another factor that is also thought to influence employers' performance is organizational support. Organizational support theory 
places every value and support of employers as well as employers trust in the performance of an organization. According to [11], the relationship of the employers' performance and the organization occur since the beginning of the recruitment/employers selection process [12]. The importance of POS on employers' performance as a moderating variable has been conducted by [13] \& [14].

On the other hand, personality problems of every Customer Service $(C S)$ are a feeling of disappointment, anger and stress when facing each bank customer. With various Bank customer's characters, CS is difficult to establish relationships. Moreover, CS is unable to control emotions in carrying out tasks, work stress due to high workload, environmental changes work and the existence of competition between the banking industries. The situation pushes CS to improve their ability that is to anticipate the fast-paced changes in the banking industry. The phenomena, undeniably, has also occurred in Kupang City, East Nusa Tenggara- Indonesia. The problems above must be immediately managed by each employer and organizational support. The attention and concern of the organization become important to improve the performance of employers and the performance of the bank itself. In some presence issues, attention and concern of the organization for every work carried out by CS, is not given serious attention. It is unsuitable since the condition will give negative impacts on other aspects. Related to the thoughts, issues, and phenomena, this research was conducted in order to examine the roles of organizational support as a moderator relationship between personality and employers' performance. It is important to be conducted in order to, as hoped, increase the performance of employers in an organization, in this case banks' employers of Kupang city, NTT- Indonesia.

\section{Review Literature And Hypothesis Development}

\section{Personality}

Personality is the dynamics of the organization in the psychophysical system between individuals who determine changes in their environment [15]. Related to the thoughts, it is found that some people are psychologically called closed (introverted) and open (extroverted), or a combination of both. [16] state that personality is a dynamic organization in an individual's psychophysiological system that determines how to adapt to its environment.

There are 2 models of personality theory instrument that are generally used in personality measurement. According to Trait theory, the models are (1) the Myers-Briggs Type Indicator / MBTI Model and (2) Big Five Personality. [16] asserted that the MBTI Model classifies individuals in 4 characters namely; 1) extraverts versus introverts, 2) sensitive or intuitive, 3) thoughts and feelings and, 4) understanding or judgment. In the other hands, The Big Five / Five-Factor Model (FFM) proposed by [2] divides individuals into 5 dimensions, including 1) Nerostism, 2) extraverted, 3) openness to experience, 4) approval, and 5) sincerity.

\section{Personality and Job Performance}

[3], [4], \& [5] conclude that there are some differences in the five (5) personality traits. According to them, caution and extraverted behaviour influence employers' performance, emotional stability has the most important influence while approval and openness do not make a difference to employers' performance. [6]; assert that personality influences teacher performance in China. Based on the thoughts, we declare H1: Personality positively influences $C S$.

\section{Job performance}


Performance is what employers do and do not do [15]. The elements, based on their statement, include 1) the quantity of work, 2) the quality of work, 3) the timeliness of work, 4) attendance at work, and 5) the ability to work together.

\section{Organizational Support}

[17] state that Perceived Organizational Support (POS) is defined as employers' perceptions about the extent to which the organization can provide support to employers and the extent to which the organization's readiness to assist. They also state that employers consider their work as a reciprocal relationship that reflects the relative dependence that exceeds formal contracts with their organizations. It means that employers and organizations are involved in reciprocal relationships.

Next, [17] indicate that three main categories of treatment perceived by employers have a relationship with POS include: 1) Justice, 2) supervisor support, 3) Organizational Appreciation, and 4) Working Conditions.

\section{Organizational Support and Job Performance}

[11] state that employers' views of POS are strongly influenced by their perceptions of organizational commitment that is shown to them. [18] argue that POS is positively related to employers' orientation towards the organization, subjective well-being, and has important implications for improving welfare. Cullen, et al (2014) assert that POS mediates a positive and significant relationship between adaptability and employers' perceptions of uncertainty about performance and job satisfaction. POS has got a positive influence on employers' performance [17]. [20] \& [21] argue that POS improves employers' performance. Based on the statements above, we declare our hypotheses, H2: Organizational support has got a positive effect on the performance of $C S$.

\section{Organizational Support as a Moderator}

Some previous studies which underlie this research, include the studies of [13] and [14] have driven to the next hypothesis, H3: Organizational support moderates the relationship between personality influences and CS performance.

Based on theoretical studies and previous research, a conceptual framework model can be presented in the following Figure.

Figure 1. Conceptual Model Scheme of This Study

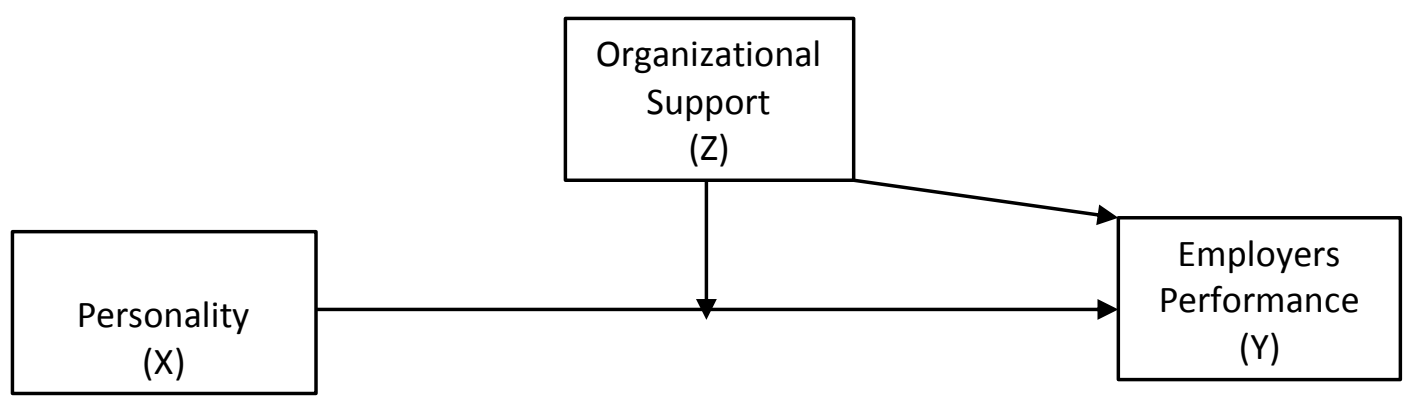

\section{Research Method}




\section{Sampling and Research Procedures}

The research was conducted on employers of Customer Service of government and private banks in Kupang City, NTT- Indonesia. The total population is 120 CS. With the sampling techniques of Slovin 5\%, 92 respondents were selected. The selection was based on proportional random sampling technique from each bank.

\section{Measurement of Variables}

\section{Personality}

Personality instruments adopted 5 indicators of Big Five Personality proposed by [2], among others; neuroticism, openness to experience, extrusion, approval and awareness.

\section{The performance.}

The customer service performance instrument adopted [22] and [23]. They are quality of work, the quantity of work, and overall work.

\section{Organizational Support.}

The POS instrument adopted [11] and [24] which include: concern, leadership support and appreciation and working conditions. All statement items use a 5-point Likert Scale. The indication is started by 'strongly agree' (5) to 'strongly disagree' (1).

\section{Data Analysis}

This study used an analysis tool of multivariate analysis, namely Moderated Regression Analysis (MRA) using SPSS Version 20.

\section{Results}

\section{Statistics Analysis}

1) Descriptive Statistics

Based on the analysis results, it is found that the average respondents' answer towards the personality variable is 3.71 ; organizational support is 3.78 , and employers' performance is 3.72). Overall, they are categorized as agreed / good.

2) Measurement Instrument

Measurement instruments applied validity and reliability tests. The validity test results refer to the Pearson Correlation Value. Each item of personality variables is between scores $(\mathrm{r}=$ $0.624-r=0.825)$; POS variable is at score $(r=0,692-r=0,841)$ and employers' performance variable is between score $(r=0,603-r=0,850)$. The reliability test results applied the Cronbach Alpha Value. The reliability value of personality using Cronbach Alpha Value ( $\alpha$ $=0.77)$; organizational support $(\alpha=0.70)$ and employers' performance $(\alpha=0.78)$.

3) Moderation Regression Analysis

Moderation Regression Analysis (MRA) is different from subgroup analysis since it used an analytical approach that maintained sample integrity and provides a basis for controlling the influence of moderator variables (Ghozali, 2016). The following is a summary of the output of MRA as seen in the following Table.

Table 1. Summary of MRA Outputs 


\begin{tabular}{|c|c|c|c|c|}
\hline Stage & Unstandardized Coefficients & $\begin{array}{l}\text { Adjusted } \\
\text { R Square }\end{array}$ & $\mathbf{t}_{\text {count }}$ & Sig \\
\hline $\begin{array}{l}\text { 1. Performance CS }=\text { Personality- } \\
\text { Performance }\end{array}$ & $0.096+1,198$ Personality & 0.989 & 90,955 & 0,000 \\
\hline $\begin{array}{l}\text { 2. CS Performance }=\text { Organizational } \\
\text { Support-performance }\end{array}$ & $2,037+1,633$ Duk. Org & 0.948 & 40364 & 0.000 \\
\hline $\begin{array}{l}\text { 3. Performance }=\text { Personality } * \\
\text { Organizational support }\end{array}$ & $\begin{array}{l}\text { 2719-0200 Personality support + } \\
0.022\end{array}$ & 0.980 & 12006 & 0.000 \\
\hline
\end{tabular}

Based on Table 1 above, by comparing the results of the three regression models, it can be concluded that $\beta 2 \neq 0$ (significant) and $\beta 2 \neq 0$ (also significant) so that it can be stated that organizational support is a quasi-moderator variable. Sharma, et al (1981) affirmed that quasi moderator occurs when the moderator variable $(\mathrm{Z})$ is related to criterion $(\mathrm{Y})$ and or predictor $(\mathrm{X})$ but the moderator variable $(\mathrm{Z})$ does not interact with the predictor $(\mathrm{X})$.

\section{Discussion and Conclusion}

The results of this study indicate that $\mathrm{H} 1$ is accepted. $\mathrm{H} 1$ states that there is a positive and significant relationship between personality and employers' performance. Statistically, it is proven true. This is evidenced by the T value calculation of 90,955 at a significant level of 0,000 $(p<0.05)$ and an Adjusted $\mathrm{R}$ Square value of 0.989 . The results of this study support the assertion of Bhatti, et al [3]; Yang and Hwang (2014); Ayub, et al (2017); [5]; [6]; Bartone et al (2009); Masood, et al (2017); Cortina, et al (1992); Akca (2017), Garbarino, et al. (2012); and Garbarino, et al. (2013). Theoretically, Robbins [1], More, et al (2006); claims that FFM model personality is more appropriate to be used in measuring the performance of employers. McCrae and Costa [2] argue that FFM personality can improve one's performance in the organization. Understanding neuroticism, approval, sincerity, openness to experience, and extraverts should be able to be considered by every individual. They are important to be understood since organization, especially CS in the banking industry has always faced a high level of competition in the bank industry.

The second objective of this study is to answer hypothesis 2; organizational support has a positive and significant effect on CS performance. The results of the analysis showed that the T-count value was 40,364 at a significant level of 0,000 with an alpha value $(p<0.05)$ and an Adjusted R Square value of 0.948 . The results of this analysis showed that it was important since organizational support improved employers' performance. [11] asserts that it is important for an organization to be concerned for the needs and welfare of employers. It is a kind of the organization's efforts to carry out its obligations for members.

The results of this study are in line with several previous studies, namely; [18], [19], [20], [21]. In order to improve CS performance, organizational support from each bank leader in Kupang City is needed. This becomes very important considering the competition among banks in getting customers by improving the quality of banking services in the form of products (goods) and services.

The third objective is to identify organizational support in moderating the relationship between personality and CS performance. The results of the analysis showed that organizational support moderated the positive and significant relationship between personality and CS performance. These results are shown in Table 1 above. The T-value calculation obtained 12,006 at a significant level of $0,000(p<0.005)$ and an Adjusted R Square value 0.980. It 
means that organizational support has a strong influence on the relationship between personality and CS performance.

The results of this study support [13] \& [14]. Improving employers' performance requires organizational support. The support is not only from the personality of each individual but also from the organization itself. Facing the competition in the banking industry, especially in Kupang City, all factors must be considered. Therefore, it is stated that personality factors and organizational support are important in improving employers' performance, in this case, the performance of CS.

\section{Limitation and Research Implication}

Undeniably, the current research is still limited. Some limitations of the research include; 1) the research focus was only on CS performance; 2) the research was limited to the institution of commercial banks; 3) the research was focused on personality factors towards performance. Based on the limitation, we suggest the following points. For the future studies, it is suggested to 1) review other factors that affect performance in the banking industry; 2) expand the object of analysis not only in CS but also employers in other work units; 3) direct at a comparative test on the comparison of employers' performance in state-owned banks with private banks.

The results of this study also provide theoretical implications in the development theory and study of employers' performance and organizational behaviour. Practically, this research implied the banking industry in Kupang city to improve its performance by (1) paying attention to the personality of each employer, and (2) supporting bank leaders for the needs and welfare of employers. By applying the suggestion, it is believed that the organizational goals can be achieved.

\section{References}

[1] Robbins, S.P., 2013, Perilaku Organisasi. Edisi Lengkap. Alih Bahasa : Benyamin Molan. Penerbit : PT. Index.

[2] McCrae, R.R and Costa Jr., P.T. 1997, Personality Trait Structure as a Human Universality. Americant Psychologist. Vol 52. No 5. 509-516.

[3] Bhatti, M. A., Battour, M M, Ismael, A. R., and Sundram, V. Pandiyan. 2013, Effects of personality traits (big five) on expatriates adjustment and job performance.

[4] Yang, Cheng-Liang and Mark Hwang. 2014. Personality Traits and simultaneous reciprocal influence between job performance and job satisfaction. Chinese Management Studies, Vol. 8 Issue: 1, pp.626.

[5] Sartori, Riccardo., Arrianna Constantini., Andrea Ceshi and Andrea Scalco. 2016. Not only correlations: a different approach for investigating the relationship between the Big Five personality traits and job performance based on workers and employees perception. Published Springer, Qual Quant 51:2507-2519.

[6] Kawiana, I Gede Putu., Luh Komang Candra Dewi., Luh Kadek Budi Martini., dan Ida Bagus Raka Suardana. 2018. The Influence of Organizational Culture, Employee Satisfaction, Personality, and Organizational Commitment Towards Employee Performance. International Research Journal of Management, IT and Social Sciences. Vol. 5 No. 3, pp.35-45

[7] Suliman, Abubakr., AbdelRahman A. AbdelRahman and Adeija Abdalla. 2010. Personality traits and work performance in a duty-free industry. International Journal of Commerce and Management, Vol. 20 Issue: 1, pp.64-82. 
[8] Shang, Kuo-Chung., Ching-Cheng Chao and Taih-Cherng Lim. 2016. The Application of personality traiyts model on the freight forwarding service industry. Maritime Business Review, Vol. 1 Issue 3, pp.231-252.

[9] Indarti, Sri., Solimun., Adji Achmad Rinaldo Fernades and Wardhani Hakim. The Effect of OCB in realtionship between personality, organizational commitment and job satisfaction on performance. Journal of Management Development, Vol. 36 Issue: 10, pp.1283-1293.

[10] Sawyerr, Olukemi O., Shanthi Srinivas and Sijun Wang. 2009. Call Center employee personality factors and service performance. Journal of Service Marketiing, Vol. 23, pp.301-317.

[11] Eisenberger, R., Robin Huntington., Steven H., Debora Sowa. 1986. Perceived Organizational Support. Journal of Applied Psychology. Vol. 71, No. 3. Pp.500-507.

[12] Lee, J., Peccei, R., 2007. Perceived organizational support and affective commitment: the mediating role of organization-based self-esteem in the context of job insecurity. J. Organ. Behav. 28 (6), 661-685

[13] Cheng, J.C., Yen, C.H., Chen, C.Y., Teng, H.Y., 2016. Tour leaders' job crafting and job outcomes: the moderating role of perceived organizational support. Tourism Manage. Perspect. 20 (5), 1929

[14] Hur, W.M., Moon, T.W., Jun, J.K., 2013. The role of perceived organizational support on emotional labor in the airline industry. Int. J. Contemp. Hosp. Manage. 25 (1), 105-123.

[15] Batilmurik, R. W., \& Noermijati, A. 2019. Organizational commitment of police officers: A static study technique in Indonesian national police. Journal of Advanced Research in Dynamic and Control Systems, 11(02-Special Issue), 1876-1884.

[16] Robbins, S.P., and Judge, T.A., 2008, Perilaku Organisasi. Edisi 12. Buku 2. Terjemahan oleh Diana Angelica. Jakarta. Penerbit : Salemba Empat.

[17] Eisenberger, R., Rhoades L, and Arneli S. 2001. Affective Commitment To Organization: The Contibution of Perceived Organizational Support. Journal of Applied Psychology, 86: pp.825-836.

[18] James N., R. Eisenberger., Michael T. Ford., Louis C. Buffardi., Kathleen A. Stewart and Cory S. Adis. 2015. Perceived Organizational Support Meta-Analytic Evaluation of Organizatinal Support Theory. Journal of Management. Vol. XX, No. XMonth XXXX 1-31.

[19] Cullen, Kristin L., Bryan D. Edwards., Wm. Camron Casper, and Kevin R. Gue. 2014. Emplyees' Adaptability and Percepetion of Change-Related Uncertainty: Implications for Perceived Organizational Support, Job Satisfaction, and Performance. Springer. J. Bus Psychol, Vol. 29, pp.269-280.

[20] Arshadi, Nasrin and Ghazal Hayavi. 2014. The effect of perceived organizational support on affective commitment and job performance: Mediating role of OBSE.

[21] Yavas, Ugur., Osman M. Karatepe and Emin Babakus. 2010. Relative efficacy of organizational support and personality traits in predicting service recovery and job performance: a study of frontline employees in Turkey. Tourism Review. Vol 65, Iss 3, pp.70-83.

[22] Brown, T.J., Mowen, J.C., Donavan, D.T. and Licata, J.W. (2002), "The customer orientation of service workers: personality trait effects on self-and supervisor performance ratings", Journal of Marketing Research, Vol. 39 No. 1, pp. 110-119.

[23] Licata, J.W., Mowen, J.C., Harris, E.G. and Brown, T.J. (2003), "On the trait antecedents and outcomes of service worker job resourcefulness: a hierarchical model approach", Journal of the Academy of Marketing Science, Vol. 31 No. 3, pp. 256-271.

[24] Boateng, Francis D., and Guangzhen Wu. 2018. Effect of Organizational Support and Police Effectiveness and behavior: a Cross cultural-comparison. Asian J. Criminol. https://doi.org/10.1007/s11417-018-9272-2 